\title{
The personal and the political: An introduction
}

\author{
Mary Nash
}

Introduced by Mary Nash, Life member, former editor of Social Work Review, 1993-96, and Senior Lecturer in Social Work at Massey University, School of Health and Social Sciences.

‘Changing Directions?' Ann Opie, (1993). Social Work Review, 6(1), 14-19

The article I have chosen to introduce to readers was a keynote paper presented to the 'Reclaiming our Voices' ANZASW conference in Wanganui in 1993 by Ann Opie. In 'Changing Directions?' Ann presents her thoughts in story form, using history and personal experience to reflect on her chosen topic - changing directions as problematised in relation to social work now and in the future. We can now look back to 1993, 15 years ago, and consider the directions in which we have moved and where we are heading.

Ann worked in Edinburgh, at Edinburgh University Settlement in the late 1960s, shortly before I went to Edinburgh to do my professional training. She describes how she gradually recognised the force of structural inequalities impeding the achievements of volunteers working in the Settlement. She went on to remind listeners of the excitement of 1968, the year of student uprisings, the optimism and determination of that generation to change things for a better world.

And then Ann reflects on her social work training and discusses the very same tensions that I too experienced on my (contemporary) training course. The tensions arose between the clients' hopes of help and advocacy to alleviate poverty and the social workers' psychodynamic approach to practice. This was a time of change for social work and the first shift towards the emergence of what would become strengths-based and solution-focused ways of thinking and working. I agree with Ann, social work in the UK in the 1970s was optimistic ... it was comparatively well-resourced and there was a feeling among practitioners that we could achieve change provided we went about it the right way. In 1993, Ann was wondering where we would now place our profession on a scale of 1 to 10 where 1 is marginalised, poorly resourced and institutionalised, while 10 is visionary, well-resourced and accepted by the communities within which it operates. How would readers respond to the question today?

How routinised has social work become? How well are we holding to our professional potential for therapeutic interventions? How successful have we been in the development of quality social work practice, including community development and change?

Where supervision is concerned, we have improved and can be optimistic. Where social work education is concerned, we need to be honest about how much Aotearoa New Zea- 
land is willing to pay in order to produce, employ and retain qualified social workers with knowledge, skills and imagination, capable of providing services second to none for service users who, in the end, have a right to such services.

Ann's conclusion was challenging in 1993 and it still is. Do we believe we can make a difference and are we prepared to take the necessary risks involved in such a project? This would make for excellent discussions in every one of our Branches in 2009. I am aware that in choosing their articles, several contributors to this vintage issue have focused on educational themes and there may be a reason for this. I believe that those with the power to influence the directions to be taken for training and educating social workers in Aotearoa New Zealand are experiencing the tensions involved in deciding between shorter (and therefore cheaper) courses, or longer (and therefore more expensive) courses, and functional practitioners or professional and less domesticated professionals. The final decision will tell us something about the relative strengths of pragmatism and idealism in today's political climate.

\section{Changing directions?}

\section{Anne Opie}

\section{Anne Opie is a lecturer in Social Work at Victoria University}

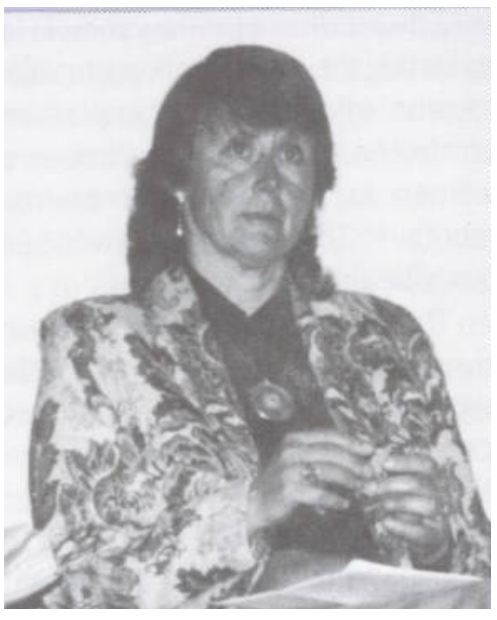

I have been asked to tell my own story and relate this to issues pertinent to social work, particularly in relation to reclaiming the voices of social work. I have called my paper 'Changing Directions?' I want to problematise both words: what has changed? And in what directions might social work in Aotearoa New Zealand move in order to more fully reclaim its voices?

I have not placed my story in much of a chronological framework. My story moves between the beginnings of my career in social work at the end of the late 1960s in Edinburgh and in the early 1970s in London and then jumps to Wellington, half a world away from the United Kingdom and 25 years later where I am now doing research into the effectiveness of social work in the health field. As with all 'beginnings' the 'beginning' I have chosen is an arbitrary beginning. There were other beginnings, other moments which shaped and informed by career and practice but which I have not included here.

I want to begin my story with some vignettes.

Late 1967 to early 1968. It is winter in Edinburgh - grey and cold and dark, with dawn breaking at $9.30 \mathrm{am}$ and dark descending about $2.30 \mathrm{pm}$. Since I work in a building where my office is effectively below ground, I feel that I am living in darkness. My work is to organise students who want to do voluntary work for the Edinburgh University Settlement. I learn 